\title{
IAMJ
}

INTERNATIONAL

AYURVEDIC

MEDICAL JOURNAL

Review Article

ISSN: 2320-5091

Impact Factor: 6.719

\section{PSYCHOSOCIAL IMPACT OF COMMON SKIN DISORDERS - A REVIEW STUDY}

\section{$\underline{\text { Manish Choudhari }}^{1}$, $\underline{\text { Nikita Jamadari }}^{2}$ Naresh Jain $^{3}$}

${ }^{1}$ P.G. Scholar, Department of Kayachikitsa in Govt. (Auto) Dhanwantari Ayurvedic College \& Hospital, Ujjain, (M.P.), India

${ }^{2}$ P.G. Scholar, Department of Kayachikitsa in Govt. (Auto) Dhanwantari Ayurvedic College \& Hospital, Ujjain, (M.P.), India

${ }^{3}$ Associate Professor, Department of Kayachikitsa in Govt. (Auto) Dhanwantari Ayurvedic College \& Hospital Ujjain, (M.P.), India

\section{Corresponding Author: choudhari.manish007@gmail.com}

\section{https://doi.org/10.46607/iamj2009072021}

(Published Online: July 2021)

Open Access

(C) International Ayurvedic Medical Journal, India 2021

Article Received: 20/06//2021 - Peer Reviewed: 24/06/2021 - Accepted for Publication: 25/06/2021

\section{Check for updates}

\begin{abstract}
Objective - To increase awareness of the psychosocial impact of Kushtha, Visarpa, Mukhadushika, Sheetpitta, Udarda and Kotha in Ayurveda and Acne vulgaris, Urticaria, Various types of fungal infections, Atopic dermatitis, Psoriasis etc. in modern point of view. Quality Of Evidence - A literature review was based on a MEDLINE search (1966 to 2000). Selected articles from the dermatologic and psychiatric literature, as well as other relevant medical journals, were reviewed and used as the basis for discussion of how skin disease affects patients' lives and of appropriate management. Message - Dermatologic problems hurt patients' quality of life. skin disease can produce stress, anxiety, anger, depression, low self-esteem, embarrassment, and other psychological, personal, professional and social life problems that affect patients' lives in ways comparable to arthritis or other disabling illnesses, as well as showing a bidirectional relationship between skin disease and psychological distress. This review focuses on the effects of five common skin diseases seen by family physicians- Acne, Urticaria, Various types of fungal infections, Atopic dermatitis and Psoriasis. Conclusion - How skin disease affects psychosocial well-being is underappreciated. Increased understanding of the psychiatric comorbidity associated with skin disease and a biopsychosocial approach to management will ultimately improve patients' lives.
\end{abstract}

Keywords: Skin disease, Psychosocial Impact, Quality of life. 


\section{INTRODUCTION}

The skin is the largest organ in the body, the skin covers just under $2 \mathrm{~m}^{2}$ in the average adult. The outer layer is the epidermis, a stratified squamous epithelium consisting mainly of keratinocytes. The epidermis is attached to but separated from, the underlying dermis by the basement membrane. The dermis is less cellular and support blood vessels, nerve and epidermal-derived appendages (hair follicles and sweat glands). Below it is the subcutis, consisting of adipose tissue ${ }^{[1]}$. and skin serves many functions, including acting as a barrier, immune regulator, and endocrine organ, as well as also having an aesthetic role ${ }^{[2]}$. The prevalence of psychiatric morbidity in dermatological outpatients is reported to be $25 \%{ }^{[3]}$. Skin disease can have a devastating effect on a person's physical and psychological wellbeing. Many chronic skin diseases such as chronic urticaria, hidradenitis suppurativa, and vitiligo have significant effects on quality of life. Chronic skin conditions have been well reported to

\begin{tabular}{l|}
\hline - Anger. \\
\hline - Anxiety. \\
\hline - Avoidance. \\
\hline - Bullying \\
\hline - Depression \\
\hline - Embarrassment. \\
\hline - Exhaustion. \\
\hline - Frustration. \\
\hline - Guilt. \\
\hline - Helplessness. \\
\hline - Increased alcohol intake. \\
\hline - Irritability. \\
\hline - Low confidence. \\
\hline
\end{tabular}

affect a patient's quality of life on multiple dimensions, including the psychosocial domain. Psychosocial is defined as the interrelation of social factors with an individual's thoughts and behaviour. Dermatological diseases can increase the risk of developing or worsening an existing psychiatric disorder. Skin diseases can have profound physical, psychological and social consequences for those who live with them, for careers and family members. Whilst the physical symptoms are diverse, all have the potential to impact one's mental wellbeing. It is for this reason that in 2003, the AllParty Parliamentary Group on Skin (APPGS) decided to conduct an enquiry into the psychological and social effects of skin diseases. In addition to assessing the extent to which skin diseases affected peoples' daily lives, the enquiry sought to produce several recommendations designed to influence the future planning and delivery of care.

-Poor body image.

- Relationship issues.

- Resentment.

- Secretiveness.

- Sexual problems.

- Sleep deprivation/sleeplessness.

- Social isolation.

- Stress.

- Suicidal thoughts.

- Suicide.

- Teasing.

- Withdrawal.

- Performance Issues

Detailed description of some skin disorders like Kushtha, Visarpa, Mukhadushika, Sheetpitta, Udarda and Kotha in Ayurveda and acne, urticaria, various types of fungal infections, atopic dermatitis and psoriasis etc in modern point of view.

\section{In Ayurveda}

- Kushtha (Leprosy): “Kushnati Vapu Iti Kushtham" The disease in which the skin gets deformed is called Kushtha. "Twachah Kurwanti Vaivarnaya Dushtah Kushthamushanti Tat” [4].
The disease in which the skin discolouration and deformity is called Kushtha.

- Visarpa (Eerysipelas): "Vividham Sarpati Yato Visarpasten Sa Smrutah. Parisarpoathava Namna Sarvatah Parisarpanat ${ }^{[5]}$. The disease which travels from its many moves to all parts of the body, that disease called Visarpa.

- Mukhadushika (Acne vulgaris): "Shalamalikantakaprakhyah Kaphamarutashonitaih. Jayante Pidika Yunam Vaktre Ya Mukhadushikah" [6]. Due to 
the Prakopa of Kapha, Vata, and Rakta Dosha on the face of young people, there is a Pidika (Boil) like Shalmali Kantaka (Thorn), which is called Mukhadushika.

- Sheetpitta (Urticaria): "Shitamarutasamsparshat Pradushto Kaphmautto. Piten Sah Sambhuya Bahiantarvisarpatah" "7]. Due to exposure to cold air, the Kapha and Vata Doshas get contaminated and mixed with Pitta causes deformity in the outer skin and in the rakta etc Dhatus, which is called Sheetpitta.

- Udarda (This is a slightly chronic stage of urticaria): "Varatidashtasansthana Shotha Sanjayate Bahih. Sakanduh Todabahulashchhardi Jwara Vidahawan. Udardamiti Tam Vidyatsheetapittamathapare. Vatadhikam Sheetpittam Udardastu Kaphadhikah" "[8]. Inflammation similar to the swelling that arises due to the bite of "Varati" on the skin is called Udarda. There is itching, pricking pain, fever and burning sensation. Some Aacharyas call this Sheetpitta. The difference between these two is that Vata Dosha predominates in Sheetpitta and Kapha Dosha predominates in Udarda.

- Kotha (This is more of a chronic stage than a urticaria): "Asamyakavamanoudirnapittashleshmaannnigrahe Mandalani Sakanduni Ragvanti Bahuni Cha Utkothah Saanubandhshcha Kotha Itybhidhiyate" ${ }^{[9]}$. Itchy red rashes emerge on the skin due to excess or cessation of vomiting, or by stopping the flow of enlarged Kapha-Pitta or by stopping the release of anna along with passage vomitus. Due to frequent rashes, they are called Kotha or Utkotha.

\section{FROM A MODERN POINT OF VIEW}

Acne Vulgaris: Face is considered an important part of the body as beautiful, and look is concerned. Acne is a chronic inflammation of the pilosebaceous units. It is extremely common, generally starts during puberty and has been estimated to affect over $90 \%$ of adolescents ${ }^{[10]}$. Acne is such a condition that disfigures the face from teenagers to younger age. Acne vulgaris is the most common skin disease of the pilosebaceous gland. It is characterized by the formation of open and closed comedones (non-inflammatory lesions) papules, pustules and nodulocystic lesions (inflammatory lesions) generally affecting the face, arm and back region. Disease in the world affecting approximately $85 \%$ of teenagers ${ }^{[11]}$. Acne change in the skin's appearance may give rise to a changed body image that, in turn, is known to lead to anger, fear, shame, anxiety, depression, embarrassment, and stigmatization within peer groups. Its substantial influence is likely related to its typical appearance on the face and would also explain the increased unemployment rate of adults with acne ${ }^{[12]}$.

Urticaria: Urticaria (hives) are a red, raised, and an itchy skin rash that is sometimes triggered by an allergen. An allergen is something that produces an allergic reaction. it is also known as urticaria. Acute urticaria may be associated with angioedema of the lips, face, tongue, throat and, rarely, wheezing, abdominal pain, headaches and even anaphylaxis. Urticaria present for less than 6 weeks is acute, and chronic if it continues for more than 6 weeks ${ }^{[13]}$. In urticaria, the examination may be unremarkable or weals may be evident and the skin should be stroked firmly with an orange stick to ascertain whether dermographism is present or not ${ }^{[14]}$. Fungal Infections: Fungal skin infections can be superficial (dermatophytes and yeasts) or, less commonly, deep (chromomycosis or sporotrichosis); the latter is seen more often in tropical climates or the immunocompromised. Dermatophyte infections (ringworm) are extremely common and usually caused by fungi of the Microsporum, Trichophyton and Epidermophyton species and present with skin (tinea corporis), scalp (tinea capitis), groin (tinea cruris), foot (tinea pedis) and/or nail(onychomycosis) involvement [15].

Atopic Dermatitis: Atopic dermatitis is a common inflammatory skin disease that takes the form of severe hardship for both the patient and the caregiver ${ }^{[16,17,18]}$. When an infant is infected with atopic dermatitis, the sensitivity of the skin of infants is altered, which impairs the emotional development of infants as the skin serves both sensory perception and communication.

Psoriasis: Psoriasis is a long-lasting, noncontagious autoimmune disorder characterized by raised areas of 
abnormal skin. These areas are purple, red and some people with darker skin, itchy, dry and scaly. Psoriasis is generally thought to be a genetic disease that is triggered by environmental factors. Symptoms often worsen during winter and with certain medications like $\beta$-blockers or NSAIDs and infections and psychological stress can also play a role ${ }^{[19,20]}$.

\section{THE IMPACT OF COMMON SKIN DISEASE-}

Psychological Impact: Various types of skin diseases can be caused or aggravated by mental stress, personality traits and mental illnesses, these skin diseases can also cause secondary mental disorders. In dermatologic patients, depression and anxiety are commonly seen in up to $25 \%-43 \%{ }^{[21-24]}$. Some skin conditions such as acne vulgaris occur predominantly in the adolescence period, a developmental period in which there is considerable focus on appearance. The impact of skin disease on teenagers' self-esteem during this period can be devastating. Evidence submitted to a recent APPG on Body Image enquiry showed appearance was the focus of bullying in $56 \%$ of cases. In situations where a child has experienced negative reactions towards their skin, there may be a risk of developing 'body-specific shame proneness that clinical experience suggests may become generalized to long-term appearance sensitivity.' Recent studies have indicated that the development of acne vulgaris later in life or having the condition continue into early adulthood can be associated in some cases with high levels of distress. October $1^{\text {st }}$ marks the annual urticaria day; a day to spread awareness about this surprisingly common condition. Most of us probably know the physical symptoms of urticaria as you might call it. But there are can also be significant psychological effects of urticaria. When the problems persist, it can have a big impact on someone's mental wellbeing, causing embarrassment, anxiety, or being a distraction from daily life. Patients with fungal infections like ringworm, candida, onychomycosis, etc., suffer from depression, anxiety, and irritability. Patients with fungal infections like ringworm, candida, onychomycosis, etc., suffer from depression, anxiety, and irritability. Patients with severe atopic dermatitis have high levels of depression. Depression is often linked to decreased quality of life due to insomnia deprivation because of the intense pruritus, this sleep deprivation can lead to emotional problems and impaired thinking. One study found that $20 \%$ of patients with severe psoriasis were on anti-depressant medication.

Social Impact: It has been suggested that patients with moderate-to-severe acne suffer from poor body image, low self-esteem and experience social isolation and constriction of activities. In this study, $68 \%$ of patients reported acne-affected their social activities. Negative influence on social/leisure activities showed a statistically significant correlation $(P<0.05)$ to gender, site of lesions, and grade of acne. Patients responded that they especially avoided social gatherings during an episode of acute acne flare as they felt other people stared at their acne and this made them uncomfortable. The patient with urticaria does not like to go to different types of Gatherings or even if he goes, the people of the gathering look at him with disgust. Due to various types of fungal infections, the image of the patient gets spoiled in the society, he hesitates to go to the meeting due to which many patients also try to suicide. Atopic dermatitis is commonly seen in children, in this disease there is an interaction affects between families and patients. In atopic dermatitis, mainly children have behavioural problems like dependency, clinginess, and fearfulness. One study found that $20 \%$ of patients with psoriasis said that they had been rejected and stigmatised by the public because of their condition.

\section{CONCLUSION}

Although this article has divided the quality-of-life impact of common skin disease into psychological and social domains, there is inevitably overlap between these categories. Physicians should keep in mind the negative effects of common skin disorders because mere treatment according to the severity of the diseases does not give a complete solution to the suffering of the patient. Apart from this, the treatment should also be done keeping in mind the mentality, sociability, and quality of life of the patient. Doctors and society should not hatred, malice and discriminate the patients with such skin disorders, but should be loving with them so that their self-esteem is not hurt. By treating patients with love, their self-confidence increases, the patient confidently tells the doctor about his 
diseases. By doing this, many skin patients can avoid mental diseases like depression, anxiety, suicidal tendencies, and their attachment to society and life does not end.

\section{REFERENCES}

1. Sir Stanley Davidson, Davidson's Principles and Practice of Medicine, $23^{\text {rd }}$ Edition 2018, Part 3 Clinical Medicine, Chapter no.29 Dermatology, Page no.1212.

2. Verhoeven EWM et al. Skin diseases in family medicine: Prevalence and health care use. Ann Fam Med. 2008;6(4): 349-54.

3. Picardi A et al. Psychiatric morbidity in dermatological outpatients: An issue to be recognized. Br J Dermatol. 2000; 143(5):983-91.

4. Astangahrdatam, Edited with Nirmala Hindi Commentary by Dr Brahmanand Tripathi Chaukhambha Sanskrit Pratishthan Delhi, Reprint:2019, Nidaansthana 14/3, page no. 527.

5. Charak Samhita, Vidyotini Hindi Commentary by Pt. Kasinatha Sastri and Dr Gorakha Natha Chaturvedi, Editor by Pt. Rajeshwardatta Shastri, Vol-2, Chaukhambha Bharati Academy Gokul Bhawan Varanasi, Reprint:2016, Chikitsasthana 21/11, Page no.589.

6. Sushruta Samhita, Susrutavimarshini Hindi Commentary by Aacharya Priyavrita Sharma, Editor Dr Anantram Sharma, Vol-1, Chaukhambha Bharati Academy Varanasi, Reprint:2013, Nidaansthana 13/40, Page no.559.

7. Madhavanidanam of Sri Madhavakara with the Sanskrit Commentary, Madhukosa by Vijayaraksita \& Srikanthadatta, Edited with Vimala-Madhudhara Hindi Commentary \& Notes by Dr Brahmananda Tripathi, Vol-2, Chaukhambha Surbharati Prakashan Varanasi, Reprint:2019, Sheetpittodardkothanidaanam 50/1, Page no.221.

8. Madhavanidanam of Sri Madhavakara with the Sanskrit Commentary, Madhukosa by Vijayaraksita \& Srikanthadatta, Edited with Vimala-Madhudhara Hindi Commentary \& Notes by Dr Brahmananda Tripathi, Vol-2, Chaukhambha Surbharati Prakashan Varanasi, Reprint:2019, Sheetpittodardkothanidaanam 50/3,4, Page no.222.

9. Madhavanidanam of Sri Madhavakara with the Sanskrit Commentary, Madhukosa by Vijayaraksita \& Srikanthadatta, Edited with Vimala-Madhudhara Hindi Commentary \& Notes by Dr Brahmananda Tripathi, Vol-2, Chaukhambha Surbharati Prakashan Varanasi, Reprint:2019, Sheetpittodardkothanidaanam 50/6, Page no.223.

10. Sir Stanley Davidson, Davidson's Principles and Practice of Medicine, $23^{\text {rd }}$ Edition 2018, Part 3 Clinical Medicine, Chapter no.29 Dermatology, Page no.1241.
11. James WD. Clinical practice. Acne. N Engl J Med. 2005;352(14):1463-72.

12. Cunliffe WJ. Acne and unemployment. Br J Dermatol. 1986;115(3):386).

13. Sir Stanley Davidson, Davidson's Principles and Practice of Medicine, $23^{\text {rd }}$ Edition 2018, Part 3 Clinical Medicine, Chapter no.29 Dermatology, Page no.1252.

14. Sir Stanley Davidson, Davidson's Principles and Practice of Medicine, $23^{\text {rd }}$ Edition 2018, Part 3 Clinical Medicine, Chapter no.29 Dermatology, Page no.1253.

15. Sir Stanley Davidson, Davidson's Principles and Practice of Medicine, $23^{\text {rd }}$ Edition 2018, Part 3 Clinical Medicine, Chapter no.29 Dermatology, Page no.1239.

16. Lynn SE, Lawton S, Newham S, Cox M, Williams HC, Emerson R. Managing atopic eczema: the needs of children. Prof Nurse 1997;12(9):622-5.

17. Graham-Brown R. Managing adults with atopic dermatitis. Dermatol Clin 1996;14(3):531-7.

18. Koblenzer PJ. Parental issues in the treatment of chronic infantile eczema. Dermatol Clin 1996;14(3):423-7.

19. Menter A, Gottlieb A, Feldman SR, Van Voorhees AS, Leonardi CL, Gordon KB, et al. (May 2008). "Guidelines of care for the management of psoriasis and psoriatic arthritis: Section 1. Overview of psoriasis and guidelines of care for the treatment of psoriasis with biologics". Journal of the American Academy of Dermatology. 58(5):826-50.

20. National Institute of Arthritis and Musculoskeletal and Skin disease. 12 April 2017 from the original 22 April 2017. Retrieved 22 April 2017.

21. Hughes J E, Barraclough BM, Hamblin LG, White JE. Psychiatric symptoms in dermatology patients. $\mathrm{Br} \mathrm{J}$ Psychiatry 1983: 143: 51-54.

22. Cohen A D, Ofek-Shlomai A, Vardy DA, Weiner Z, Shvartzman P. Depression in dermatological patients identified by the Mini International Neuropsychiatric Interview questionnaire. J Am Acad Dermatol 2006:54: 94-99.

23. Aktan S, Ozmen E, Sanli B. Psychiatric disorders in patients attending a dermatology outpatient clinic. Dermatology 1998: 197: 230-234.

24. Wessely S C, Lewis GH. The classification of psychiatric morbidity in attenders at a dermatology clinic. $\mathrm{Br}$ J Psychiatry 1989:155: 686-691.

\section{Source of Support: Nil \\ Conflict of Interest: None Declared}

How to cite this URL: Manish Choudhari et al: Psychosocial Impact Of Common Skin Disorders - A Review Study. International Ayurvedic Medical Journal \{online\} 2021 \{cited July 2021\} Available from: http://www.iami.in/posts/images/upload/1452_1456.pdf 